\title{
Outbreaks and factors influencing microbiological contamination of fresh produce
}

\author{
Yukiko Wadamori, Ravi Gooneratne and Malik A Hussain* \\ Department of Wine, Food and Molecular Biosciences, Lincoln University, Lincoln 7647, New \\ Zealand
}

*Correspondence to: MA Hussain, Department of Wine, Food and Molecular Biosciences, Lincoln University, Lincoln 7647, New Zealand. Email : malik.hussain@lincoln.ac.nz

\begin{abstract}
Fresh fruits and vegetables are nutritionally well-recognized as healthy components in diets. The microbiological foodborne outbreaks associated with the consumption of fresh produce have been increasing. Salmonella spp., E. coli O157:H7, Staphylococcus aureus, Campylobacter spp. and Listeria monocytogenes are the most common pathogens that contaminate fresh produce. This review discusses recent foodborne outbreaks linked to fresh produce, factors that affect microbiological contamination and measures that could be adopted to reduce the foodborne illnesses.
\end{abstract}

Keywords:

fresh produce; E. coli O157:H7; Staph. aureus; Salmonella spp.; antibiotic resistance

\section{INTRODUCTION}

Microbiological food safety has always been a focus of the food industry and public health agencies since foodborne pathogens cause many illnesses and deaths worldwide. According to Eurosurveillance editorial team [1], a total of 5,048 outbreaks of foodborne illnesses occured in the European Union (EU) in 2011. The most common pathogens responsible were Campylobacter $(220,209$ cases) followed by Salmonella $(95,548)$ and pathogenic E. coli $(9,485)$. New food consumption trends indicate that people are interested in fresh produce because of the many essential nutrients for health and wellbeing are present in them. Vegetable and fruit production have been increasing and their average consumption per capita has risen from 45 to $54 \%$ from 1976 to 2009 in the USA [2] and this trend has continued.

The number of the foodborne outbreaks linked to the consumption of fresh produce have also increased, with an estimated $14.8 \%$ in 1998 to $22.8 \%$ in 2007 in the USA [3]. Table 1 lists some of the recent foodborne outbreaks

This article has been accepted for publication and undergone full peer review but has not been through the copyediting, typesetting, pagination and proofreading process, which may lead to differences between this version and the Version of Record. Please cite this article as doi: $10.1002 /$ jsfa.8125

This article is protected by copyright. All rights reserved. 
associated with fresh produce recorded between 2013 and 2016. It is interesting to note that the type of pathogen responsible for each outbreak was different (Table 1). Only some selected examples are used to demonstrate the diversity of pathogens involved in fresh produce contamination. Outbreaks of Yersinia pseudotuberculosis in New Zealand in 2014 and Cyclospora cayetanensis in the USA in 2013 and 2014 were two of the most significant outbreaks associated with fresh produce. However, Salmonella and Listeria monocytogenes are emerging as two major bacterial pathogens of concern in terms of fresh produce safety (Table 1).

Contamination can occur at any point, from the farm to plate. According to World Health Organization (WHO) [4], a hazard can exist in production systems due to several factors: post-harvest practices, water, local environment, fertilizer, worker health and hygiene, and consumption patterns and practices. Cross-contamination components to Listeria levels in fresh produce was reported a significant factor [97]. As fresh produce is normally consumed raw or with minimum proccesing, it is important to keep the microbial load of fresh produce as low as possible to prevent foodborne illnesses. This review discusses the contamination types of fresh produce, recent outbreaks (2013-2016), frequency of foodborne outbreaks (in selected countries) and factors affecting the microbial food safety of fresh produce as well as future implications of microbiological contamination of fresh produce.

Table 1. Foodborne outbreaks associated with fresh produce (2013 - 2016)

\begin{tabular}{|c|c|c|c|}
\hline Year/Country & Produce involved & Pathogen/cases & References \\
\hline 2016/Australia & Rock melon & $\begin{array}{l}\text { Salmonella Hvittingfoss } \\
\text { (97 cases) }\end{array}$ & {$[88]$} \\
\hline 2016/Australia & Pre-package lettuce & $\begin{array}{l}\text { Salmonella anatum } \\
\text { (144 cases) }\end{array}$ & {$[33]$} \\
\hline 2016/UK & Imported salad & $\begin{array}{l}\text { E. coli O157 } \\
\text { (161 cases, } 60 \text { hospitalised, } 2 \text { deaths })\end{array}$ & {$[34]$} \\
\hline 2016/USA & Packaged salads & $\begin{array}{l}\text { L. monocytogenes } \\
\text { (19 cases, } 19 \text { hospitalised, } 1 \text { death) }\end{array}$ & [89] \\
\hline 2015/Australia & $\begin{array}{l}\text { Imported frozen } \\
\text { strawberries }\end{array}$ & $\begin{array}{l}\text { Hepatitis A virus } \\
\text { (19 cases) }\end{array}$ & {$[90]$} \\
\hline 2015/USA & Imported cucumber & $\begin{array}{l}\text { Salmonella Poona } \\
\text { (>900 cases, } 204 \text { hospitalised, } 6 \text { deaths) }\end{array}$ & [91] \\
\hline 2014/USA & $\begin{array}{l}\text { Prepackaged caramel } \\
\text { apples }\end{array}$ & $\begin{array}{l}\text { L. monocytogenes } \\
\text { ( } 32 \text { cases, } 31 \text { hospitalised, } 6 \text { deaths) }\end{array}$ & [94] \\
\hline
\end{tabular}

This article is protected by copyright. All rights reserved. 


\begin{tabular}{|c|c|c|c|}
\hline 2014/USA & Mung bean sprouts & $\begin{array}{l}\text { L. monocytogenes } \\
\text { ( } 5 \text { cases, } 5 \text { hospitalised, } 2 \text { deaths) }\end{array}$ & [94] \\
\hline $\begin{array}{l}\text { 2014/New } \\
\text { Zealand }\end{array}$ & $\begin{array}{l}\text { Fresh vegetables (exact } \\
\text { source remains unknown) }\end{array}$ & $\begin{array}{l}\text { Yersinia pseudotuberculosis } \\
\text { (334 cases, } 65 \text { hospitalised) }\end{array}$ & [64] \\
\hline 2014/UK & Lettuce, cucumber & $\begin{array}{l}\text { Enteroinvasive } E \text {. coli } \mathrm{O} 96 \\
(50 \text { cases })\end{array}$ & [65] \\
\hline 2014/UK & Salads & $\begin{array}{l}\text { Salmonella singapore } \\
(4 \text { cases })\end{array}$ & [65] \\
\hline 2014/USA & Raw clover sprouts & $\begin{array}{l}\text { E. coli O121 } \\
\text { (19 cases, } 8 \text { hospitalised })\end{array}$ & [21] \\
\hline 2014/USA & Coriander & $\begin{array}{l}\text { Cyclospora cayetanensis } \\
\text { ( } 304 \text { cases, } 7 \text { of } 183 \text { hospitalised) }\end{array}$ & [21] \\
\hline 2013/USA & Bean sprouts & $\begin{array}{l}\text { S. enteritidis } \\
\text { ( } 87 \text { cases, } 27 \text { hospitalised) }\end{array}$ & [21] \\
\hline 2013/USA & Imported cucumber & $\begin{array}{l}\text { Salmonella } \\
\text { (84 cases, } 17 \text { hospitalised) }\end{array}$ & [21] \\
\hline 2013/USA & $\begin{array}{l}\text { Imported pomegranate } \\
\text { seeds }\end{array}$ & $\begin{array}{l}\text { Hepatitis A virus } \\
\text { (165 cases, } 69 \text { hospitalised) }\end{array}$ & [21] \\
\hline 2013/USA & Salad mix & $\begin{array}{l}\text { Cyclospora cayetanensis } \\
\text { (631 cases, } 50 \text { hospitalised) }\end{array}$ & [21] \\
\hline 2013/USA & Imported cucumber & $\begin{array}{l}\text { E. coli O157:H7 } \\
(33 \text { cases, } 11 \text { hospitalised })\end{array}$ & [21] \\
\hline 2013/UK & Watercress & Vero cytotoxin-producing E. coli O157 & [65] \\
\hline
\end{tabular}

\section{MICROBIAL CONTAMINATION OF FRESH PRODUCE}

According to Westrell et al. [5], Salmonella infections caused 151,995 human cases of salmonellosis in 2007, the second most prevalent in the 27 EU Member States and the four European Free Trade Association (EFTA) countries. In 1995, there was a large outbreak of Salmonella in the USA and Finland [6], originating from the seeds of alfalfa sprouts. Similarly, Mohle-Boetani et al. [7] reported seven outbreaks of Salmonella in the USA between 2000 to 2002 related to the consumption of raw mung bean sprouts. Greene et al. [8] reported a Salmonella outbreak (510 cases in 2002) due to contamination of tomatoes by S. newport, a rare strain of Salmonella. Fresh produce-associated salmonellosis outbreaks are becoming common and new strains or serotypes were identified in the recent outbreaks. In 2015, Salmonella Poona was identified in an outbreak linked to cucumber (>900 cases, 204 hospitalised, 6 deaths) in USA [91]. This year so far two Salmonella 
outbreaks in Australia have been attributed to fresh produce; Salmonella anatum outbreak (144 cases) linked to pre-package lettuce and Salmonella Hvittingfoss (97 cases) linked to rock melons [33, 88].

The incidence of food poisoning caused by E. coli O157:H7 have been on the increase. In 1995, E. coli O157:H7 was detected in 40 patients (13 hospitalized) in the USA, and 70\% of these patients reported having consumed leaf lettuce [9]. In 1996, E. coli O157:H7 poisoning occurred most likely from white radish sprouts with 7,996 people ill, 398 hospitalized, and three deaths [10]. E. coli O157:H7 has also been traced to sprouts [11], cantaloupes, apples and leaf lettuce [9, 12]. Wachtel and Charkowski [13] reported that 72 cases of E. coli O157:H7 poisonings in the USA in 1999 were from shredded iceberg lettuce. Westrell et al. [5] reported a total of 2,905 cases of E. coli O157:H7 poisonings in 27 EU Member States and the four European Free Trade Association (EFTA) countries.

In 2016, a national level outbreak of a rare strain of E. coli O157 associated with mixed salad leaves was investigated by the Public Health England (PHE). This specific strain of E. coli causes infection with symptoms ranging from mild diarrhoea to bloody diarrhoea with severe abdominal pain. This recent outbreak had a total of 161 cases (England 154, Wales 6 and Scotland 1) with 60 hospitalisations and 2 deaths [34].

Staph. aureus is also a major cause of foodborne diseases. This bacterium generally exists in nasal mucosa, skin and hair of animals and sometimes produce enterotoxins [15]. Of the total food poisoning cases in the UK, 1 to 6\% between 1969 and 1981, 0.5 to $1 \%$ between 1982 and 1990 were caused by Staph. aureus [16]. This foodborne pathogen was attributed to $1.5 \%$ of all outbreaks $(\mathrm{N}=2530)$ from 1992 to 2009 in UK and ranked as the sixth most common bacterial causes during this period [35]. One of the common origins of Staph. aureus is from meat products but any product can be contaminated by $S$. aureus because it can be passed on to produce from the skin of workers [16]. It is commonly detected in fresh vegetables, with $56.9 \%$ of salad vegetables purchased from street vendors in India [17] and all vegetables purchased from five different shops in Bangladesh [18] contaminated with Staph. aureus.

L. monocytogenes is a well-known pathogen for which mortality is sometimes higher than for other pathogens [2]. According to Lim et al. [19], 23 listeriosis notifications were reported in New Zealand in 2010, 31 people hospitalized and seven died. Eighty-five percent of the listeriosis illnesses were estimated to be foodborne [14]. In 2010, the number of New Zealand listeriosis poisonings were higher in females, the most vulnerable being women over 70 years old (deaths occurred in those over 70 years old) [19]. The most dangerous factor was underlying illness $(68.8 \%)$ or receiving immunosuppressive drugs $(52.9 \%)$. The trend of the number of the This article is protected by copyright. All rights reserved. 
outbreaks has fluctuated over the years. Lim et al. [19] reported that L. monocytogenes isolates were confirmed in 22 New Zealanders in 2010. In 2011, during a multi-state listeriosis outbreak in the USA caused by L. monocytogenes in cantaloupe, $99 \%$ of patients were hospitalized and 33 patients $(22 \%)$ died in the USA [20]. Prevalence of Listeria In fresh produce was reported in several investigation [3, 32, 71, 96, 97] Fresh produce-associated listeriosis outbreaks are regularly occurring in the USA: 2014, mung bean sprouts (5 cases, 5 hospitalised, 2 deaths); 2014, caramel apple (32 cases, 31 hospitalised, 6 deaths); and 2016, packaged salads (19 cases, 19 hospitalised, 1 death) [89, 94].

Figure 1 shows the contribution of the different of pathogens associated with foodborne outbreaks of fresh produce in the USA between 1998 and 2012 [21]. According to the Center for Disease Control and Prevention (CDC) [21] in the USA, between 1998 and 2012, 889 outbreaks out of 16,576 were related to fresh produce but the pathogen type was identified only in 699 cases. As seen in figure 1, norovirus was the most common, followed by Salmonella and Enteropathogenic E. coli. Norovirus and hepatitis A viruses are the most important foodborne viruses where fresh produce has been recognised as a transmission vehicle. This article primarily discusses bacterial pathogen in fresh produce. Some recent publications have addressed the problem of foodborne viruses in fresh produce $[86,87]$. Table 2 lists selected studies on microbial contamination of fresh produce or cut vegetables. All these studies showed similar results for the level of contamination with aerobic plate count (APC) and the presence of pathogens.

This article is protected by copyright. All rights reserved. 


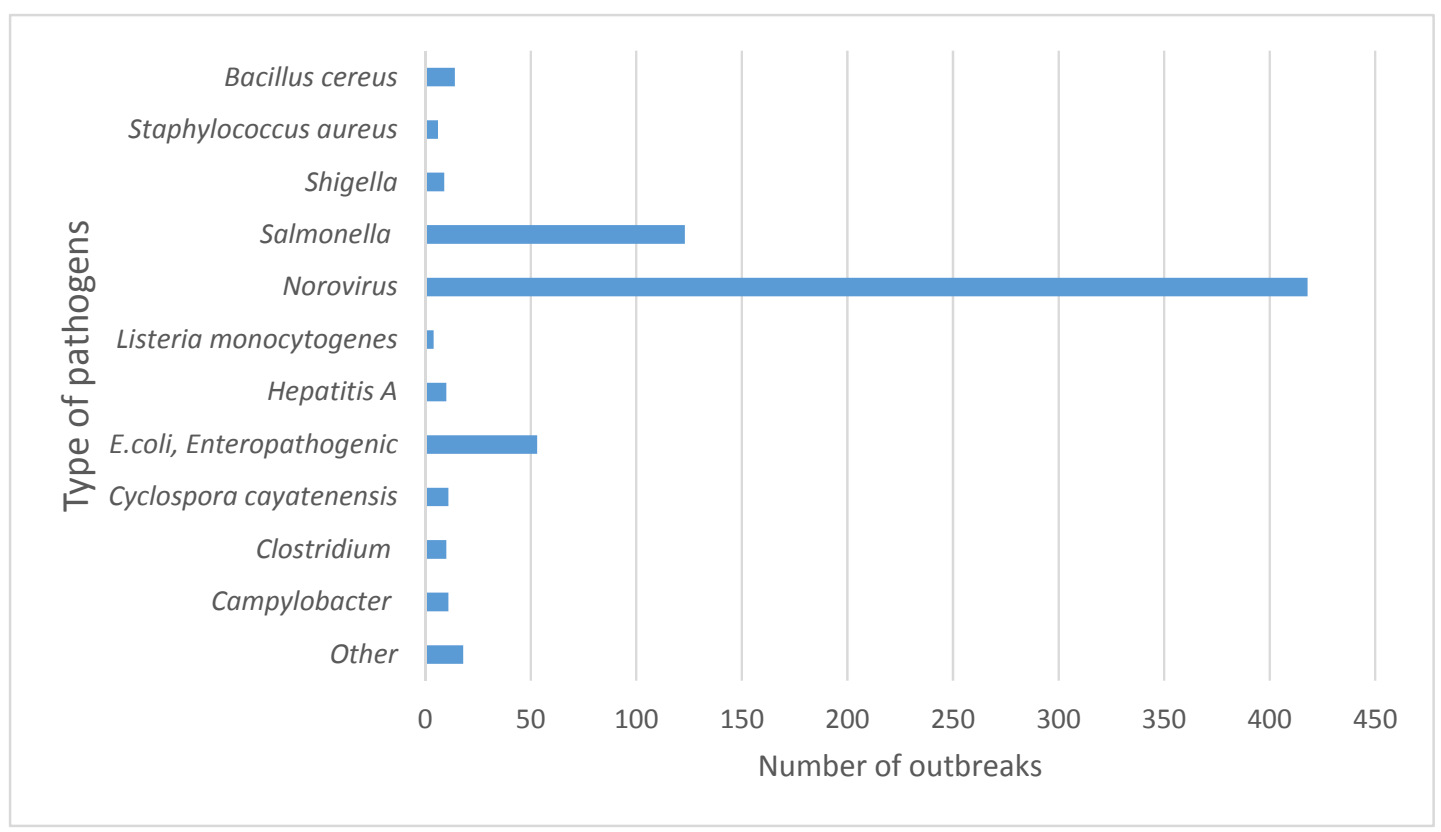

Figure 1. Foodborne pathogens linked to outbreaks caused by contaminated fresh produce in the USA between 1998-2012 [21]

Table 2. Selected reports of microbial contamination of fresh produce

\begin{tabular}{|c|c|c|}
\hline Produce & Microbial contamination level & References \\
\hline $\begin{array}{l}\text { Raw salad vegetables } \\
\text { (parsley, lettuce, radish) }\end{array}$ & $\begin{array}{l}\text { E. coli } 0.7-7 \log _{10} \mathrm{CFU} / \mathrm{g} \text {; Total coliform } 1.69-8.16 \mathrm{CFU} / \mathrm{g} \\
\text { L. monocytogenes }(14 \%) \text {; Staph. aureus }(45.5 \%)\end{array}$ & [95] \\
\hline Whole vegetables & L. monocytogenes $5.7 \%$. & {$[32]$} \\
\hline $\begin{array}{l}\text { Mix salad, ready-to-eat } \\
\text { (RTE) salads and sprouts }\end{array}$ & $\begin{array}{l}\text { APC } 10^{7}-10^{8} \mathrm{CFU} / \mathrm{g} ; \text { E. coli } 40 \% \text {; Salmonella } 1.3 \% \text {; and } L \text {. } \\
\text { monocytogenes } 0.7 \% \text {. } \\
\text { No Y. enterocolitica; E. coli } \mathrm{O} 157: \mathrm{H} 7 \text {; and Campylobacter. }\end{array}$ & {$[66]$} \\
\hline Whole vegetables & APC 0-7.4 $\log _{10} \mathrm{CFU} / \mathrm{g}$; E. coli 0-3.8 CFU/g. & [67] \\
\hline $\begin{array}{l}\text { Fruits and vegetables, } \\
\text { packed RTE vegetables }\end{array}$ & $\begin{array}{l}\text { APC } 10^{0}-10^{10} \mathrm{CFU} / \mathrm{g} \text {; coliform } 10^{0}-10^{10} \mathrm{CFU} / \mathrm{g} \text {; yeast and } \\
\text { mold } 10^{1}-10^{9} \mathrm{CFU} / \mathrm{g} \text {. }\end{array}$ & {$[68]$} \\
\hline $\begin{array}{l}\text { Whole vegetables, RTE } \\
\text { vegetables, mixed salads } \\
\text { and mixed lettuce }\end{array}$ & $\begin{array}{l}\text { Salmonella } 0.75 \% \text { of the whole vegetables; L. monocytogenes } \\
1.61 \% \text { of the whole vegetables; and } 0.29 \% \text { in RTE samples. } \\
\text { No E.coli O157:H7. }\end{array}$ & {$[69]$} \\
\hline $\begin{array}{l}\text { Whole vegetables, herbs } \\
\text { and fruits }\end{array}$ & $\begin{array}{l}\text { APC } 10^{4}-10^{8} \mathrm{CFU} / \mathrm{g} ; \text { L. monocytogenes } 0.64 \% \text {. } \\
\text { No Salmonella; Shigella; or E. coli O157:H7. }\end{array}$ & {$[70]$} \\
\hline Whole vegetables & $\begin{array}{l}\text { E. coli } 8.94 \% \text {; L. monocytogenes only in organic } 1.12 \% \text {. } \\
\text { No E. coli O157:H7; Salmonella. }\end{array}$ & [71] \\
\hline Whole vegetables & APC $10^{6}-10^{7} \mathrm{CFU} / \mathrm{g} ;$ E. coli $41.5 \%$ - organic and $40 \%{ }^{-}$ & [72] \\
\hline
\end{tabular}

This article is protected by copyright. All rights reserved. 


\begin{tabular}{|c|c|c|}
\hline & $\begin{array}{l}\text { traditional. } \\
\text { No Salmonella. }\end{array}$ & \\
\hline $\begin{array}{l}\text { Mix vegetables and } \\
\text { whole vegetables }\end{array}$ & $\begin{array}{l}\text { Aeromonas } 34 \% \text {. } \\
\text { No E. coli; E. coli } \mathrm{O} 157: \mathrm{H} 7 \text {; Salmonella; Listeria; or } \\
\text { Campylobacter. }\end{array}$ & {$[73]$} \\
\hline Whole vegetables & $\begin{array}{l}\text { APC } 10^{5} \mathrm{CFU} / \mathrm{g} \text { traditional, } 10^{6} \mathrm{CFU} / \mathrm{g} \text { organic; E. coli } 12.9 \% \\
\text { traditional and } 22.2 \% \text { organic. } \\
\text { No E. coli O157:H7; L. monocytogenes; or Salmonella. }\end{array}$ & {$[74]$} \\
\hline Whole vegetables & $\begin{array}{l}\text { Not satisfactory E. coli; Listeria. } \\
\text { No Campylobacter; E. coli O157:H7; or Salmonella. }\end{array}$ & [75] \\
\hline $\begin{array}{l}\text { Whole vegetables and } \\
\text { fruits }\end{array}$ & $\begin{array}{l}\text { APC } 10^{1}-10^{9} \mathrm{CFU} / \mathrm{g} \text {. } \\
\text { No E. coli; or Salmonella. }\end{array}$ & {$[76]$} \\
\hline Whole vegetables & APC $10^{5}-10^{6} \mathrm{CFU} / \mathrm{g}$. & [39] \\
\hline $\begin{array}{l}\text { Whole vegetables, } \\
\text { sprouts and fruits }\end{array}$ & $\begin{array}{l}\text { APC } 10^{9}-10^{10} \mathrm{CFU} / \mathrm{g} \text {; E. coli } 39.2 \% \text {; Staph. aureus } 58.3 \% \text {; and } \\
\text { Salmonella } 28.3 \% \text {. }\end{array}$ & [17] \\
\hline Whole vegetables & $\begin{array}{l}\text { E. coli } \mathrm{O} 157: \mathrm{H} 70.11 \% \text {; L. monocytogenes } 0.11 \% \text {; and } \\
\text { Salmonella } 0.38 \% \text {. }\end{array}$ & [3] \\
\hline
\end{tabular}

\section{FREQUENCY OF FRESH PRODUCE RELATED FOODBORNE OUTBREAKS}

According to the Center for Science in the Public Interest (CSPI) [22], of 4,638 outbreaks (117,136 cases) of foodborne illnesses in the USA from 1998 to 2007,57 to $70 \%$ of them could not be traced to the contamination source. The most frequent source was seafood ( 838 outbreaks) followed by fresh produce (684 outbreaks), poultry (538 outbreaks) and pork (200 outbreaks) [22]. Vegetables contributed to 33\% (228 outbreaks) and about 50\% (345 outbreaks) to dishes of produce including salads [22]. In New Zealand, 716 food poisoning outbreaks occurred in $2012,13.3 \%$ of which were from leafy vegetables $>$ root vegetables $(10 \%)>$ fruits and nuts $(6.7 \%)>$ stalk vegetables $(3.3 \%)$ [23]. The most common pathogen was Norovirus $(27 \%)$ followed by Salmonella spp. (20\%) and Campylobacter spp. (17\%)[23]. Table 3 shows the frequency of the foodborne outbreaks linked to fresh produce contamination between 2002 and 2012.

In the USA, the number of fresh produce outbreaks have fluctuated but not declined (Table 3). On average, the USA had 57 outbreaks due to fresh produce contamination each year. In Japan the frequency of foodborne outbreaks (bacteria, viruses and chemicals) related to fresh produce declined by 33\% between 2002 and 2012 [24] (Table 3). Table 3 also presents the data for fresh produce (vegetables, fruits and nuts) in New Zealand [25]. On average, New Zealand now report 3 times more fresh produce linked outbreaks compared to in 2002.

In general, it is hard to highlight a specific trend in the incidence of such outbreaks between 2002 and 2012.

This article is protected by copyright. All rights reserved. 
However, in 2012, there were 5 times as many outbreaks than a decade ago. It is apparent from above that fresh produce is a considerable contributor towards foodborne outbreaks throughout the world.

Table 3. Frequency of foodborne outbreaks linked to fresh produce contamination between 2002 and 2012 for USA [21]; Japan [24]; and New Zealand [25]

\begin{tabular}{|c|c|c|c|}
\hline \multirow{2}{*}{ Year } & \multicolumn{3}{|c|}{ Frequency of fresh produce-associated outbreaks in selected countries } \\
\cline { 2 - 4 } & USA & Japan & New Zealand \\
\hline 2002 & 53 & 12 & 2 \\
\hline 2003 & 45 & 9 & 2 \\
\hline 2004 & 81 & 5 & 2 \\
\hline 2005 & 51 & 8 & 8 \\
\hline 2006 & 78 & 8 & 4 \\
\hline 2007 & 47 & 10 & 1 \\
\hline 2008 & 63 & 6 & 6 \\
\hline 2009 & 41 & 5 & 10 \\
\hline 2010 & 58 & 5 & 6 \\
\hline 2011 & 49 & 9 & 10 \\
\hline 2012 & 60 & 8 & $\mathbf{6}$ \\
\hline Yearly average & $\mathbf{5 7}$ & $\mathbf{8}$ & 10 \\
\hline
\end{tabular}

Figure 2 shows the number of Salmonella positive samples in fresh produce in the EU from 2011 to 2012 [26]. The number of Salmonella positive samples differed between countries, probably because each country sets its own safety guidelines to manage food safety of fresh produce. In 2011, only 3 countries (Denmark, Germany and Belgium) in the EU had Salmonella positive samples, but in 2012, 8 countries (Denmark, Germany, Hungary, Netherlands, Poland, Romania, Belgium and Spain) had Salmonella positive samples. Fresh produce industry is not very well-regulated for microbiological safety and testing. European commission for Agriculture and Rural Development published microbiological criteria for foodstuffs in November 2005 (Commission Regulation (EC) No 2073/2005, Official Journal L 338 of 22 December2005, p. 1). Regular testing of fresh, uncut and unprocessed vegetables and fruits, excluding sprouted seeds against the criterion is considered not useful in normal circumstances. However, testing of E. coli and Salmonella for processed fresh produce (pre-cut fruit and vegetables, unpasteurised fruit and vegetable juices) and Salmonella for sprouted seeds is required to ensure safety. This indicates management of food safety was not that effective in the EU member countries at this stage. An effective management system for fresh produce could be set up to correct this.

This article is protected by copyright. All rights reserved. 


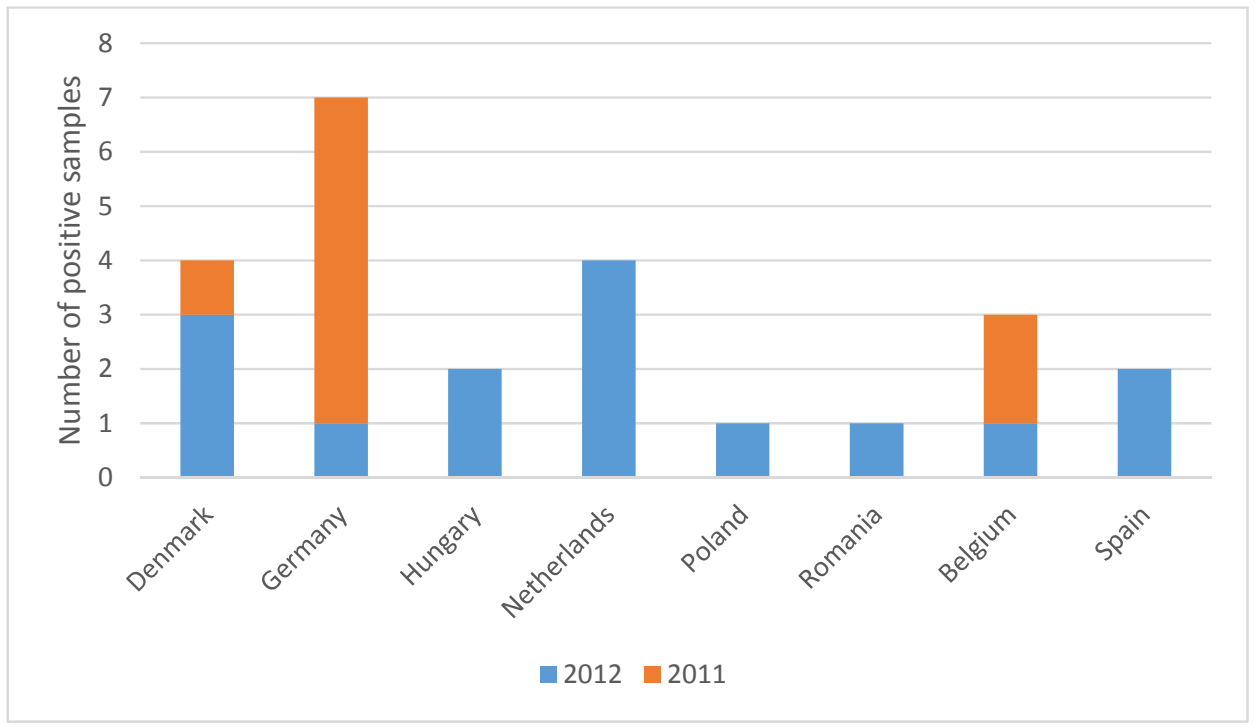

Figure 2. Number of Salmonella positive samples in fresh produce in the European Union countries from 2011 to 2012 [85]

\section{FACTORS THAT AFFECT MICROBIAL CONTAMINATION OF FRESH PRODUCE}

There are many intrinsic and extrinsic factors that favour microbial growth. Firstly, the moisture content in fresh produce is approximately $\mathrm{a}_{\mathrm{w}}=0.97-1.00$, which is favourable for microbial growth. The optimum moisture content for growth of Salmonella spp., enterohemorrhagic E. coli and Campylobacter spp. is 0.99, for Staph. aureus it is 0.98 and the minimum moisture content for L. monocytogenes is 0.92 [27]. The problem is that it is difficult to reduce the moisture content of fresh produce unless it is processed. Secondly, $\mathrm{pH}$ is an important factor because each microbe type has an optimal $\mathrm{pH}$ for its growth. According to Koutsoumanis and Sofos [28], E. coli $\mathrm{O} 157: \mathrm{H7}$ and S. Typhimurium can tolerate even acidic $\mathrm{pH}$ (to $\mathrm{pH} 5.0$ ), while L. monocytogenes grows only to $\mathrm{pH}$ 6.0. According to the US Food and Drug Administration (FDA) [27], pH 4.6 is about the minimal $\mathrm{pH}$ for growth of most pathogens. However, there are some pathogens, such as C. botulinum, that can withstand acidic $\mathrm{pH}$ as low as $\mathrm{pH}$ 4.2. Several researchers including Kim and Hung [29] used electrolyzed oxidizing water to change the surface $\mathrm{pH}$ of blueberries and this was effective in reducing the microbial load. A third factor is the presence of different types of nutrients in fruits and vegetables, such as proteins, fat, minerals and vitamins. Sugars and proteins are the most common energy source for pathogens. However, some pathogens require special nutrients to grow. For example, Staph. aureus requires biotin for its growth [30], while the growth of Salmonella increases in the presence of iron (compared to a non-iron environment) [31]. Since each vegetable

This article is protected by copyright. All rights reserved. 
has a different nutrient composition, analyzing optimal pathogen growth on different types of vegetables by analyzing their nutrients requires further study.

Oxidation-reduction (or redox) potential (ability of materials to oxidize or reduce) of the food also influences the pathogen growth of. According to Snyder [36], oxidation-reduction potential varies between food types and has a profound effect on the growth of some microorganisms such as C. botulinum [37]. The redox potential of a food is controlled by many factors, such as $\mathrm{pH}$, packaging and types of ingredients in a food. Normally the redox potential of fresh produce is low [27]. Guentzel et al. [38] analyzed the effect of redox potential on E. coli, S. Typhimurium, Staph. aureus, L. monocytogenes and Enterococcus faecalis using electrolyzed oxidizing water at a near-neutral $\mathrm{pH}$ condition and reported that all microbial counts were markedly reduced. This method has no side effects and therefore is an excellent way to improve food safety of fresh produce without application of chemicals or antimicrobial agents.

Antimicrobial agents which originate from natural or artificial materials have a strong impact on pathogen growth. Sirsat and Neal [39] used vinegar (2.5\% acetic acid) on E. coli and Salmonella and reported that it significantly reduced microbial count (2 to $3 \log _{10} \mathrm{CFU} / \mathrm{g}$ ). Similarly, Medina et al. [40] reported that the effect of vinegar, olive oil and several beverages including wine were effective in controlling the growth of certain pathogens (S. enteritidis, L. monocytogenes). According to Gálvez et al. [41], many lactic acid bacteria can produce bacteriocins through lactic fermentation, which can act as an antimicrobial agent. Vidhyasagar and Jeevaratnam [42] reported that the bacteriocin produced from one of the lactic acid bacterial species (Pediococcus pentosaceus VJ13) has antimicrobial effects on Mycobacterium smegmatis, Klebsiella pneumonia, C. perfringens and Staph. epidermidis. Since bacteriocins are effective and produce only minimal side effects, investigations into applying it to fresh produce would be helpful. In addition, the US FDA [27] reported that there are many types of artificial antimicrobial agents (preservatives or additives) such as nitrates and nitrites, sulfur dioxide, acetic acid and nisin that could be used to control or eliminate foodborne pathogens in fresh produce.

Food processing conditions also affect pathogen growth. Firstly, the packaging or product environment has a significant impact on pathogen growth. According to Sun et al. [43], chlorine dioxide gas significantly reduced the total bacterial count, E. coli, yeast, and mould concentration on fresh blueberries. Simon et al. [44] reported 
that an optimum concentration of gases (low oxygen and high carbon dioxide concentrations) could be determined for each product to minimize microbial growth. Thompson [45] reported that oxygen, nitrogen and carbon dioxide are the most important gases in a modified atmosphere for pathogen control in fresh produce. Nitrogen has antimicrobial properties, oxygen is effective in controlling anaerobic microbes and carbon dioxide, which can reduce $\mathrm{pH}$ if dissolved in the liquid portion of a food, has an inherent antimicrobial activity. The recommended percentage of these gases differs for each fresh produce type. This is an area that requires further investigation.

Temperature is one of the important factors for bacterial growth. Koseki and Isobe [46] conducted an experiment on the growth of $E$. coli O157:H7 and Salmonella spp. in lettuce at different time periods ( $0 \mathrm{~h}$ to 120 h) and exposure temperatures $\left(5,10,15,20\right.$, and $\left.25^{\circ} \mathrm{C}\right)$. Bacteria increased with both time and temperature. The optimal temperature for each of the following pathogens are: S. typhi -35 to $37^{\circ} \mathrm{C}$ [47], E. coli $\mathrm{O} 157: \mathrm{H} 7-37^{\circ} \mathrm{C}$ [48], Campylobacter $-42^{\circ} \mathrm{C}$ [49], Staph. aureus $-37^{\circ} \mathrm{C}$ and L. monocytogenes $-37^{\circ} \mathrm{C}$ [50]. There is one exception as ESR [51] reported, the optimal temperature of some strains of C. botulinum (those that are proteolytic, mesophilic and produce toxins $\mathrm{A}, \mathrm{B}$ or $\mathrm{F}$, group 1 ) is $35-40^{\circ} \mathrm{C}$, but for those strains that are non-proteolytic, mesophilic and produce B, E or F type toxins (group 2) it is $18-25^{\circ} \mathrm{C}$. In addition, the minimum temperature at which C. botulinum group 2 strains can grow is only $3^{\circ} \mathrm{C}$, whereas the minimum growth for group 1 strains is $10^{\circ} \mathrm{C}$ [51]. C. botulinum is an anaerobic bacterium that causes a disease called botulism (which can be fatal). This disease tends to affect those who consume canned products stored in a cold place because inside of the canned product is an anaerobic environment. Date et al. [52] reported 3 outbreaks of botulinum poisoning caused by consumption of canned vegetables produced at home in the USA. According to these authors [52], 38\% of botulism cases occurring between 1999 and 2008 in the USA were from canned products produced at home although commercial canned products have also caused botulinum poisoning. In 2007, an outbreak of botulism in the USA was caused by canned hotdog chili sauce [53]. In order to achieve better food safety two factors are important i.e., optimal thermal processing for different kinds of products and/or packaging to kill the vegetative cells and $\mathrm{pH}$ adjustment (slight acidic) of the product to prevent spore germination.

According to Shalini and Singh [54], factors that inhibit pathogen growth are called 'hurdles'. 'Hurdle technology' (a combination of 'hurdles') should be used to prevent pathogen growth. Hurdles include the 
factors mentioned above, such as different processing methods. For fresh produce such as lettuce, radish sprouts and apples, a combination of calcium oxide and sonication was effective in lowering the pathogen load (E. coli O157:H7, L. monocytogenes and S. Typhimurium) more than sonication or calcium oxide alone [55]. Similarly, Brown et al. [56] used a combination of chlorine and lactic acid bacteria to inhibit E. coli O157:H7 and C. sporogenes in ready-to-eat spinach. It was reported that the hurdles were effective in reducing the pathogen load, except in C. sporogenes which has the ability to grow at even at low $\left(3.3^{\circ} \mathrm{C}\right)$ temperature $[56]$. In contrast, Ganesh et al. [57] used 'natural agents' as hurdles, such as malic, tartaric and lactic acids and grape seed extract as an electrostatical spray on spinach and lettuce to reduce the E. coli O157:H7 load, and found that all agents except tartaric acid were effective. As there is the possibility of using a combination of hurdles, more research could be directed to investigate the most effective hurdle combination for each fresh produce.

Table 4. Strategies that have been tested for postharvest applications

\begin{tabular}{|c|c|c|}
\hline Produce type & Strategies & References \\
\hline Leafy greens & $\begin{array}{l}\text { Bacteriophage cocktail, BEC } 8\left(10^{6} \mathrm{CFU} / \text { leaf with the essential }\right. \\
\text { oil trans-cinnameldehyde }(0.5 \% \mathrm{v} / \mathrm{v}) \text {. }\end{array}$ & {$[63]$} \\
\hline $\begin{array}{l}\text { Fresh produce (lettuce, } \\
\text { radish sprout and apple) }\end{array}$ & $\begin{array}{l}\text { Calcium oxide }(2 \% \mathrm{CaO}) \text { and sonication }(10 \mathrm{~min} \text { at a frequency } \\
\text { of } 20 \mathrm{kHz}) \text {. }\end{array}$ & {$[55]$} \\
\hline Lettuce & $\begin{array}{l}\text { Wash with calcinated calcium (the heated scallop shell } \\
\text { powder). }\end{array}$ & {$[77]$} \\
\hline Carrots & $\begin{array}{l}\text { Mildly heated }\left(45^{\circ} \mathrm{C}\right) \text {, slightly acidic electrolyzed water with } \\
\text { low available chlorine }(23 \mathrm{mg} / \mathrm{L}) \text {. }\end{array}$ & [78] \\
\hline Cauliflower & $\begin{array}{l}8 \% \text { Salt; } 0.3 \% \text { Citric acid; } 300 \mathrm{ppm} \text { Potassium metabisulphite; } \\
\text { and } 300 \mathrm{ppm} \text { Sodium benzoate. } \\
\text { Store at } 5-7^{\circ} \mathrm{C} \text {. }\end{array}$ & [79] \\
\hline Broccoli & $\begin{array}{l}\text { Irradiation with } \mathrm{UV}-\mathrm{C} \text { light }\left(8 \mathrm{~kJ} \mathrm{~m}^{-2}\right) \text { and then heating }\left(45^{\circ} \mathrm{C} \text {, }\right. \\
3 \mathrm{~h} \text { in air oven }) .\end{array}$ & {$[80]$} \\
\hline Paprika & $\begin{array}{l}\text { Wash in } 1 \% \text { calcium chloride and } 6 \% \text { calcium ascorbate } \\
\text { combined with } 50^{\circ} \mathrm{C} \text { water temperature for } 2 \mathrm{~min} \text {. }\end{array}$ & [81] \\
\hline Cantaloupe & $\begin{array}{l}\text { Hot water }\left(75^{\circ} \mathrm{C}, 1 \mathrm{~min}\right) \text {; and gaseous ozone }(10,000 \mathrm{ppm} \text {, } \\
30 \mathrm{~min}) \text {. }\end{array}$ & {$[82]$} \\
\hline Tomato & $\begin{array}{l}\text { Humidified flow of ozone-enriched air }\left(4 \pm 0.5 \mu \mathrm{L}^{-1} \text { of ozone }\right. \\
\text { for } 30 \mathrm{~min} \text { every } 3 \mathrm{~h}) .\end{array}$ & {$[83]$} \\
\hline General & $\begin{array}{l}\text { Conducting research in fresh produce safety; } \\
\text { Implementation of food safety programs; } \\
\text { Outreach education for farmers, shippers and processors; }\end{array}$ & [84] \\
\hline
\end{tabular}

This article is protected by copyright. All rights reserved. 


\section{FUTURE IMPLICATIONS}

The number of foodborne outbreaks has been variable in spite of the many measures taken to reduce the incidence. Outbreaks have varied between different countries but here is no obvious trend in the outbreaks related to fresh produce. Recent trends show that people prefer healthy foods including fresh vegetables and fruits. As fresh produce is normally eaten raw, more research is required to reduce the pathogen load on fresh produce. Currently, not many countries have regulations to monitor pathogens in fresh produce. Therefore, guidelines to manage fresh produce to prevent contamination of pathogens should be set and monitored regularly. In addition, effective technologies to manage fresh produce with materials produced from natural agents need to be tested. Examples of recommended strategies to reduce bacterial contamination in fresh produce are listed in Table 4. Although some studies report the use of natural agents as hurdles, there is little information on the combined effects of these agents $[58,59]$. Other possible hurdles reported include use of electrolyzed oxidizing water [60], bacteriocins [61], modified atmosphere [62], bacteriophage spray [63] and strict management of temperature and storage times. Publications by Qadri et al. [92] and Mukhopadhyaya and Raghupathy [93] provide further information on the fresh produce contamination and control measures. Fresh-cut fruits and vegetables is one of the growing sectors within fresh produce industry offering convenient products; however, maintaining quality and safety of such product is a major challenge [92]. Several novel preventative approaches including essential oils, green tea extract and biopreservation were proposed to reduce microbial risks. There is a need for adequate processing technologies to ensure fresh-cut produce safety and consumer acceptability [92]. In conclusion to keep fresh produce safe, further studies are required to determine how to manage contamination of pathogens and fresh produce safety throughout the supply chain.

\section{ACKNOWLEDGMENTS}

Ms YukikoWadamori completed her Master of Science degree at Lincoln University, New Zealand. Her research project was financially sponsored by the Faculty of Agriculture and Life Sciences.

\section{REFERENCES}

1. Eurosurveillance editorial team. The European Union summary report on trends and sources of zoonoses, zoonotic agents and food-borne outbreaks in 2011. Available online: http://www.eurosurveillance.org/ViewArticle.aspx?ArticleId=20449 (accessed on 15 March 2015)

2. Cook R, Tracking Demographics and U.S. Fruit and Vegetable Consumption Patterns. USA: University of California, 2011.

3. Wijnands LM, Delfgou-van Asch EH, Beerepoot-Mensink ME, van der Meij-Florijn A, Fitz-James I, et al., Prevalence and concentration of bacterial pathogens in raw produce and minimally processed packaged salads produced in and for the Netherlands. J Food Prot 77:388-394 (2014).

4. WHO. Microbiological hazards in fresh leafy vegetables and herbs, in MRA Series, World Health Organization, 2008.

This article is protected by copyright. All rights reserved. 
5. Westrell T, Ciampa N, Boelaert F, Helwigh B, Korsgaard H, Chríel M, et al. Zoonotic infections in Europe in 2007: a summary of the EFSA-ECDC annual report. Euro Surveill 14(3):pii:19100 (2009).

6. Mahon BE, Ponka A, Hall WN, Komatsu K, Dietrich SE, et al., An international outbreak of Salmonella infections caused by alfalfa sprouts grown from contaminated seeds. $J$ Infect Dis 175(4):876-882 (1997).

7. Mohle-Boetani JC, Farrar J, Bradley P, Barak JD, Miller M, et al., Salmonella infections associated with mung bean sprouts: epidemiological and environmental investigations. Epidemiol Infect 137(Special Issue 03):357-366 (2009).

8. Greene SK, Daly E, Talbot E, Demma L, Holzbauer S, et al., Recurrent multistate outbreak of Salmonella Newport associated with tomatoes from contaminated fields, 2005. Epidemiol Infect 136(2):157-65 (2008).

9. Ackers ML, Mahon BE, Leahy E, Goode B, Damrow T, et al., An Outbreak of Escherichia coli O157:H7 Infections Associated with Leaf Lettuce Consumption. J Infect Dis 177(6):1588-1593 (1998).

10. Michino H, Araki K, Minami S, Takaya S, Sakai N, et al., Massive outbreak of Escherichia coli O157:H7 infection in schoolchildren in Sakai City, Japan, associated with consumption of white radish sprouts. Am J Epidemiol 150(8):787-96 (1999).

11. Watanabe Y, Ozasa K, Mermin JH, Griffin PM, Masuda K, et al., Factory outbreak of Escherichia coli O157:H7 infection in Japan. Emerg Infect Dis 5(3):424-428 (1999).

12. Hilborn ED, Mermin JH, Mshar PA, et al., A multistate outbreak of Escherichia coli O157:H7 infections associated with consumption of mesclun lettuce. Arch Intern Med 159(15):1758-1764 (1999).

13. Wachtel MR and Charkowski AO, Cross-contamination of lettuce with Escherichia coli O157:H7. J Food Prot 65:465-470 (2002).

14. Hoffman S, Maculloch B and Batz M, Economic burden of major foodborne illnesses acquired in the United States. 2015. Available online: http://www.ers.usda.gov/media/1837791/eib140.pdf (accessed on 22 October 2016)

15. Loir YL, Baron F and Gautier M, Staphylococcus aureus and food poisoning. Genet Mol Res 2(1):63-76 (2003).

16. Wienekea A, Roberts D and Gilbert RJ, Staphylococcal food poisoning in the United Kingdom, 1969-90. Epidemiol Infect 110:519-531 (1993).

17. Viswanathan $P$ and Kaur R, Prevalence and growth of pathogens on salad vegetables, fruits and sprouts. Int J Hygien Environ Heal 203(3):205-213 (2001).

18. Rahman F and Noor R, Prevalence of Pathogenic Bacteria in Common Salad Vegetables of Dhaka Metropolis. Bang J Bot 41(2):159-162 (2012).

19. Lim E, Lopez L, Cressey P and Pirie R, Annual Report Concerning Foodborne Disease In New Zealand 2010. Available online:

http://www.foodsafety.govt.nz/elibrary/industry/FBI-report-2011.pdf (accessed on 15 April 2016).

20. McCollum JT, Cronquist AB, Silk BJ, Jackson KA, O'Connor KA, et al., Multistate outbreak of listeriosis associated with cantaloupe. N Engl J Med 369(10):944-53 (2013).

21. Centers for Disease Control and Prevention (CDC), Foodborne Outbreak Online Database (FOOD), Centers for Disease Control and Prevention, Editor. USA (2013).

22. Center for Science in the Public Interest (CSPI), Outbreak alart! 2009. Center for Science in the Public Interest Washintong DC (2009).

This article is protected by copyright. All rights reserved. 
23. The Institute of Environmental Science and Research Ltd (ESR), Annual Summary of Outbreaks in New Zealand 2012. Available online:

https://surv.esr.cri.nz/PDF_surveillance/AnnualRpt/AnnualOutbreak/2012/2012OutbreakRpt.pdf (15 April 2016)

24. Ministry of Health Labour and Wealfare, Statistics of food poisoning. (2014).

25. ESR, Annual Summary of Outbreaks in New Zealand, , ESR, Editor. (2014).

26. European Food Safety Authority and The European Union Summary Report on Trends and Sources of Zoonoses, Zoonotic Agents and Food-borne Outbreaks in 2012. EFSA J 12(2):3547 (2014).

27. U.S. Food and Drug Administration, Evaluation and Definition of Potentially Hazardous Foods in Factors that Influence Microbial Growth. US Food and Drug Administration, USA (2013).

28. Koutsoumanis KP and. Sofos JN, Comparative acid stress response of Listeria monocytogenes, Escherichia coli O157:H7 and Salmonella Typhimurium after habituation at different $\mathrm{pH}$ conditions. Lett Appl Microbiol 38(4):321-326 (2004).

29. Kim C and Hung Y-C, Inactivation of E. coli O157:H7 on Blueberries by Electrolyzed Water, Ultraviolet Light, and Ozone. J Food Sci 77(4):M206-M21 (2012).

30. Mah RA, Fung DYC and Morse SA, Nutritional Requirements of Staphylococcus aureus S-6. Appl Microbiol 4(15):866-870 (1967).

31. Kortman GA, Boleij A, Swinkels DW and Tjalsma H, Iron Availability Increases the Pathogenic Potential of Salmonella Typhimurium and Other Enteric Pathogens at the Intestinal Epithelial Interface. PLoS One 1(7):e29968 (2012).

32. $\mathrm{Wu} \mathrm{S,} \mathrm{Wu} \mathrm{Q,} \mathrm{Zhang} \mathrm{J,} \mathrm{Chen} \mathrm{M,} \mathrm{Yan} \mathrm{Z} \mathrm{et} \mathrm{al.} \mathrm{Listeria} \mathrm{monocytogenes} \mathrm{prevalence} \mathrm{and} \mathrm{characteristics}$ in retails raw foods in China. PLOS ONE 10:e136682 (2015).

33. Withewoth J, Salmonella outbreak reaches 144 probable cases. Food Quality News February 16, 2016. Available online:

http://www.foodqualitynews.com/Food-Outbreaks/Investigations-continue-into-Tripod-Farmers-sala d (accessed 18 October 2016)

34. Public Health England, UK Government. E. coli O157 national outbreak update (August 11, 2016). Available online:

https://www.gov.uk/government/news/update-as-e-coli-o157-investigation-continues (accessed 25 October 2016)

35. Health Protection Agency, UK. Foodborne outbreak surveillance and risk assessment 2009. Available online: http://www.hpa.org.uk/Topics/InfectiousDiseases/InfectionsAZ/GastrointestinalDisease/Epidemiolo gicalData/FoodborneOutbreakSurveillanceAndRiskAssessment/

36. Snyder OP, Oxidation-Reduction Potential of Food. Hospitality Institute of Technology and Management, p. 1-2 (2008).

37. Hambleton P, Clostridium botulinum. J Cheml Technol Biotechnol 59(1):113-113 (1994).

38. Guentzel JL, Liang Lam K, Callan MA, Emmons SA and Dunham VL, Reduction of bacteria on spinach, lettuce, and surfaces in food service areas using neutral electrolyzed oxidizing water. Food Microbiol 25(1):36-41 (2008).

39. Sirsat S and Neal J, Microbial Profile of Soil-Free versus In-Soil Grown Lettuce and Intervention Methodologies to Combat Pathogen Surrogates and Spoilage Microorganisms on Lettuce. Foods 2(4):488-498 (2013).

This article is protected by copyright. All rights reserved. 
40. Medina E, Romero C, Brenes M and De Castro A, Antimicrobial activity of olive oil, vinegar, and various beverages against foodborne pathogens. J Food Prot 70(5):1194-9 (2007).

41. Galvez A, Abriouel H, Lopez RL and Ben Omar N, Bacteriocin-based strategies for food biopreservation. Int J Food Microbiol 120:51-70 (2007).

42. Vidhyasagar $\mathrm{V}$ and Jeevaratnam $\mathrm{K}$, Bacteriocin activity against various pathogens produced by Pediococcus pentosaceus VJ13 isolated from Idly batter. Biomed Chromat 27(11):1497-1502 (2013).

43. Sun X, Bai J, Ference C, Wang Z, Zhang Y, et. al., Antimicrobial activity of controlled-release chlorine dioxide gas on fresh blueberries. J Food Prot 77(7):1127-32 (2014).

44. Simon A, Gonzolez-Fandos E and Obar VT, Influence of Washing and Packaging on the Sensory and Microbiological Quality of Fresh Peeled White Asparagus. J Food Sci 69(1): FMS6-FMS12 (2004).

45. Thompson AK, Controlled atmosphere storage of fruits and vegetables. Available online: http://study.syau.edu.cn/upload/530/attach/_2005500051_201110270744371.pdf (26 March 2016)

46. Koseki S and Isobe S, Prediction of pathogen growth on iceberg lettuce under real temperature history during distribution from farm to table. Int J Food Microbiol 104(3):239-248 (2005).

47. ESR. Microbial pathogen data sheets : Salmonella typhi. ESR New Zealand, (2010)

48. ESR. Microbial pathogen data sheets : Escherichia coli 157:H7. ESR New Zealand, (2010)

49. ESR. Microbial pathogen data sheets : Campylobacter. ESR New Zealand, (2010)

50. $\quad$ ESR. Microbial pathogen data sheets : Listeria monocytogenes. ESR New Zealand, (2010)

51. ESR. Microbial pathogen data sheets :Clostridium botulinum. ESR New Zealand, (2010)

52. Date K, Fagan R, Crossland S, Maceachern D, Pyper B, et al., Three outbreaks of foodborne botulism caused by unsafe home canning of vegetables--Ohio and Washington, 2008 and 2009. J Food Prot 74(12):2090-2096 (2011).

53. Juliao PC, Maslanka S, Dykes J, Gaul L, Bagdure S, et al., National outbreak of type a foodborne botulism associated with a widely distributed commercially canned hot dog chili sauce. Clin Infect Dis 56(3):376-382 (2013).

54. Singh S and Shalini R, Effect of Hurdle Technology in Food Preservation: A Review. Critical Rev Food Sci Nutr 56:641-649 (2016).

55. Yoon J-H, Bae Y-M, Jung K-S, Heu S and Lee S-Y, Combined effect of calcium oxide and sonication to reduce foodborne pathogens on fresh produce. Food Sci Biotechnol 22(1): 275-278 (2013).

56. Brown AL, Brooks JC, Karunasena E, Echeverry A, Laury A, et al., Inhibition of Escherichia coli O157:H7 and Clostridium sporogenes in Spinach Packaged in Modified Atmospheres after Treatment Combined with Chlorine and Lactic Acid Bacteria. J Food Sci 76(6):M427-M432 (2011).

57. Ganesh V, Hettiarachchy NS, Griffis CL, Martin EM and Ricke SC, Electrostatic Spraying of Food-Grade Organic and Inorganic Acids and Plant Extracts to Decontaminate Escherichia coli O157:H7 on Spinach and Iceberg Lettuce. J Food Sci 77(7):M391-M396 (2012).

58. Gupta S, Chatterjee S, Vaishnav J, Kumar V, Variyar PS, et al., Hurdle technology for shelf stable minimally processed French beans (Phaseolus vulgaris): A response surface methodology approach. LWT - Food Sci Technol 48(2):182-189 (2012).

59. Gastélum GG, Avila-Sosa R, López-Malo A and Palou E, Listeria innocua Multi-target Inactivation by Thermo-sonication and Vanillin. Food Bioproc Technol 5(2):665-671 (2012).

This article is protected by copyright. All rights reserved. 
60. Ding T, Dong Q-L, Rahman SM and Oh D-H, Response Surface Modeling of Listeria monocytogenes Inactivation on Lettuce Treated with Electrolyzed Oxidizing Water. $J$ Food Proc Engin 34(5):1729-1745 (2011).

61. Mitić-Ćulafić DS, Pavlović M, Ostojić S and Knezević-Vukčević J, Antimicrobial Effect of Natural Food Preservatives in Fresh Basil-Based Pesto Spreads. J Food Proc Preserv 38(3):1298-1306 (2014).

62. Gomes MH, Randolph MB and Domingos PFA, Influence of Oxygen and Temperature on the Respiration Rate of Fresh-cut Cantaloupe and Implications for Modified Atmosphere Packaging. HortSci 47( 8 ):1113-1116 (2012).

63. Viazis S, Akhtar M, Feirtag J and Diez-Gonzalez F, Reduction of Escherichia coli O157:H7 viability on leafy green vegetables by treatment with a bacteriophage mixture and trans-cinnamaldehyde. Food Microbiol 28(1):149-157 (2011).

64. MPI. Outbreak Source Investigation: Yersinia pseudotuberculosis 2014. MPI: New Zealand (2014). Available online: https://www.mpi.govt.nz/document-vault/11030 (22 March 2016)

65. Public Health England (PHE). Foodborne illness in humans: general outbreaks in England and Wales. (2014).

66. Abadias M, Usall J, Anguera M, Solsona C and Vinas I, Microbiological quality of fresh, minimally-processed fruit and vegetables, and sprouts from retail establishments. Int J Food Microbiol 123:121-129 (2008).

67. Aycicek H, Oguz U and Karci K, Determination of total aerobic and indicator bacteria on some raw eaten vegetables from wholesalers in Ankara, Turkey. Int J Hygien Environ Heal 209(2):197-201 (2006).

68. Badosa E, Trias R, Parés D, Pla M and Montesinos E, Microbiological quality of fresh fruit and vegetable products in Catalonia (Spain) using normalised plate-counting methods and real time polymerase chain reaction (QPCR). J Sci oFood Agri 88(4):605-611 (2008).

69. De Giusti M, Aurigemma C, Marinelli L, Tufi D, De Medici D, et al., The evaluation of the microbial safety of fresh ready-to-eat vegetables produced by different technologies in Italy. J Appl Microbiol 109(3):996-1006 (2010).

70. Johnston LM, Jaykus LA, Moll D, Martinez MC, Anciso J, et al., A field study of the microbiological quality of fresh produce. J Food Prot 68:1840-1847(2005).

71. Loncarevic S, Johannessen GS and Rorvik LM, Bacteriological quality of organically grown leaf lettuce in Norway. Lett Appl Microbiol 41(2):18618-9 (2005).

72. Maffei DF, Silveira NFA and Catanozi MPLM, Microbiological quality of organic and conventional vegetables sold in Brazil. Food Cont 29(1):226-230 (2013).

73. McMahon MAS and Wilson IG, The occurrence of enteric pathogens and Aeromonas species in organic vegetables. Int J Food Microbiol 70(1-2):155-162 (2001).

74. Oliveira M, Usall J, Vinas I, Anguera M, Gatius F, et al., Microbiological quality of fresh lettuce from organic and conventional production. Food Microbiol 27(5): 679-684 (2010).

75. Sagoo SK, Little CL and Mitchell RT, The microbiological examination of ready-to-eat organic vegetables from retail establishments in the United Kingdom. Lett Appl Microbiol 33(6):434-439 (2001).

76. Seow J, Ágoston R, Phua L and Yuk H-G, Microbiological quality of fresh vegetables and fruits sold in Singapore. Food Cont 25(1):39-44 (2012).

This article is protected by copyright. All rights reserved. 
77. Kim JG, Nimitkeatkai H, Choi JW and Cheong SR, Calcinated calcium and mild heat treatment on storage quality and microbial populations of fresh-cut iceberg lettuce. Hort Environ Biotehnol 52(4):408-412 (2011).

78. Koide S, Shitanda D, Note M and Cao W, Effects of mildly heated, slightly acidic electrolyzed water on the disinfection and physicochemical properties of sliced carrot. Food Cont 22:452-456 (2011).

79. Sinha J, Gupta E and Chandra R, Low Cost Preservation Of Cauliflower For 180 Days Through Hurdle Technology. Int J Food Nutrl Sci 2(1):27-32 (2013).

80. Lemoine ML, Civello PM, Chaves AR and Martínez GA, Effect of combined treatment with hot air and UV-C on senescence and quality parameters of minimally processed broccoli (Brassica oleracea L. var. Italica). Postharvest Biol Technol 48(1):15-21 (2008).

81. Das BK and Kim J, Combined effect of heat treatment and washing solutions on the quality and microbial reduction of fresh-cut paprika. Hortic Environ Biotechnol 51(4):257-261(2010).

82. Selma MV, Ibáñez AM, Allende A, Cantwell M and Suslow T, Effect of gaseous ozone and hot water on microbial and sensory quality of cantaloupe and potential transference of Escherichia coli O157:H7 during cutting. Food Microbiol 25(1):162-168 (2008).

83. Aguayo E, Escalona VH and Artés F, Effect of cyclic exposure to ozone gas on physicochemical, sensorial and microbial quality of whole and sliced tomatoes. Postharv BiolTechnol 39(2):169-177 (2006).

84. Alliance for Food and Farming. Analysis of Produce Related Foodborne Illness Outbreaks 2010.Available online: http://www.perishablepundit.com/docs/foodborne-illness-outbreaks.pdf ( 22 March 2016).

85. European Food Safety Authority. The European Union Summary Report on Trends and Sources of Zoonoses, Zoonotic Agents and Food-borne Outbreaks in 2012. EFSA J 12(2):3547 (2014).

86. European Food Safety Authority. Scientific Opinion on an update on the present knowledge on the occurrence and control of foodborne viruses. EFSA J 9(7):2190 (2011).

87. Li D, De Keuckelaere A and Uyttendaele M, Fate of Foodborne Viruses in the "Farm to Fork" Chain of Fresh Produce. Compreh Rev Food Sci Food Saf 14:755-770 (2015).

88. Flynn D. How did Salmonella Hvittingfoss get on Aussie rockmelons? Food Safety News (August 9 , 2016) Available online: http://www.foodsafetynews.com/2016/08/130219/\#.WA6FuotMqUk (Accessed 21 October 2016)

89. CDC. Multistate Outbreak of Listeriosis Linked to Packaged Salads Produced at Springfield, Ohio Dole Processing Facility (Final Update, March 31, 2016). Available online: http://www.cdc.gov/listeria/outbreaks/bagged-salads-01-16/ (accessed 19 October 2016)

90. The Department of Health - Australian Government. Hepatitis A linked to frozen berries (Updated February 26, 2015) Available online:

http://www.health.gov.au/internet/main/publishing.nsf/Content/mr-yr15-dept-dept002.htm (accessed 20 October 2016)

91. CDC. Multistate Outbreak of Salmonella Poona Infections Linked to Imported Cucumbers (Final Update, March 18, 2016) Available online: http://www.cdc.gov/salmonella/poona-09-15/ (accessed 19 October 2016)

92. Qadri OS, Basharat Y and Kumar A, Fresh-cut fruits and vegetables: Critical factors influencing microbiology and novel approaches to prevent microbial risks-A review. Cog Food Agri 1(1): (2015). DOI:10.1080/23311932.2015.1121606

This article is protected by copyright. All rights reserved. 
93. Mukhopadhyaya S and Raghupathy R, Application of emerging technologies to control Salmonella in foods: A review. Food Res Int 45:666-677 (2012).

94. Garner D and Kathariou S, Fresh produce-associated listeriosis outbreaks, sources of concern, teachable moments, and insights. J Food Prot 79:337-344 (2016).

95. Faour-Klingbeil D, Murtada M, Kuri V and Todd ECD, Understanding the routes of contamination of ready-to-eat vegetables in the Middle East. Food Cont 62:125-133 (2016).

96. Zhu Q and Hussain MA, Prevalence of Listeria species in fresh salad vegetables and ready-to-eat foods containing fresh produce marketed in canterbury, New Zealand. Adv Food Technol Nutr Sci Open $J$ 1:5-9 (2014).

97. Faour-Klingbeil D, Todd ECD and Kuri V, Microbiological quality of ready-to-eat fresh vegetables and their link to food safety environment and handling practices in restaurants. LWT-Food Sci Technol 74:224-233 (2016). 